\title{
An empirical investigation on factors influencing choice of foreign market by media firms
}

\author{
Ali Akbar Farhangi ${ }^{\mathrm{a}}$, Tahmoures Hassangholipour ${ }^{\mathrm{b}}$ and Ehtesham Rashidi ${ }^{\mathrm{c}^{*}}$
}

${ }^{a}$ Department of Management, Science and Research Branch, Islamic Azad University, Tehran, Iran

${ }^{b}$ Department of Management, University of Tehran, Tehran, Iran

${ }^{c}$ PhD in Media Management, Department of Economic and Management, Science and Research Branch, Islamic Azad University, Tehran, Iran

\section{H R O N I C L E}

\section{Article history:}

Received June 28, 2013

Received in revised format

19 October 2013

Accepted 23 October 2013

Available online

December 172013

Keywords:

International media

Media management

Export markets

Global marketing

International market selection

\begin{abstract}
A B S T R A C T
This study examines a number of factors suggested in the literature as important determinants of the foreign market selection. Key strategic factors are determined as four groups: hostcountry characteristics, firm-specific factors, competitive situation and content adaptation. In this study, multiple regression and path analysis are used. To test the model with modeling techniques, the necessary data from 29 media firms were used. It is based on a questionnaire, which has provided several insights into market selection elements. Our findings indicate that all components of the host country, exporting companies, competitive situation and the content adaptation could influence positively the selection of foreign market. The results also indicate that the adaptation of content was the most effective in choosing a foreign market. In addition, cross-cultural adaptation is an important component in selection of foreign markets. The results also suggest that the causal relationships between the independent variables are positive and significant, while the relationship between the content adaptation and the competitive situation has not been confirmed.
\end{abstract}

\section{Introduction}

The majority of the studies of company export behavior have utilized data obtained from all kinds of firms in a sample (Cavusgil, 1984; Chan-Olmsted, 2005; Albarran et al., 2006). Cadogan et al. (2002) extended the study of market orientation into the international arena by developing and examining hypotheses associated with the antecedents to and consequences of market-oriented activities in firms' export operations. They reported that export experience, export dependence and coordinating capabilities were positively associated with export market-oriented activities. They also reported that export market-oriented activities were positively related to aspects of export performance. Cavusgil and Zou (1994) studied the marketing strategy-performance relationship in the context of export ventures and reported that export marketing strategy was affected by internal and external factors. 
The United States is considered as the leading exporter of video media goods in the world and it is the biggest investor in theatrical films, spending well above $\$ 63$ million per theatrical production and leading the world in box-office receipts (Chan-Olmsted et al., 2008). Chan-Olmsted et al. (2008) studied the host country factors influenced the export of U.S.-based video media products, including film and television programs and reported that economic environment, geographical proximity, technological infrastructure, and market size affected the purchase of motion pictures and video programming from the United States. Besides, countries with better economic environments, implementation of intellectual property rights, political rights, larger market size and cultural differences, and language similarity appeared to import more heavily broadcasting content products from the United States. Dahringer (1991) concentrated on the international marketing of services and the requirement for service marketers to be aware of obstacles to international marketing unique to the service sector, as well as of necessary management strategies for overcoming such obstacles (Dimmick \& Rothenbuhler, 1984). Dow and Karunaratna (2006) developed and examined a range of potential psychic distance stimuli including differences in culture, language, religion, education, and political systems. They reported that, whereas the majority of the proposed indicators proved to be statistically significant predictors of trade flows, the most common psychic distance surrogate - a composite measure of Hofstede's cultural dimensions - was not significant (Dyck \& Zingales, 2002).

Erramilli and Rao (1990) attempted to describe the variation of foreign market entry mode choice in the service sector, by looking into the unique characteristics of service organizations. Koch (2001) argued that the prevalent theory approaches must be considered as two aspects of one decision process and proposed that an exhaustive list of factors, which could affect outcomes of such an integrated process be developed and argued that an inclusive spectrum of analysis could be able to accommodate all business contexts and most relevant business practice. It then presented a new market and market entry mode selection model, which conformed to the proposed inclusive spectrum of the underlying decision process analysis. Characteristics of national cultures have often been claimed to impact the selection of entry modes. Kogut and Singh (1988) investigated this claim by developing a theoretical argument for why culture should impact the choice of entry. They derived two hypotheses, which relate culture to entry mode choice, one focusing on the cultural distance between countries, the other on attitudes towards uncertainty avoidance. They provided some support for the impact of national culture on entry choice. Papadopoulos and Denis (1988) investigated the inventory, taxonomy and assessment of methods for international market selection. Whitelock and Jobber (2004) performed an assessment on external factors in the decision of UK industrial firms to enter a new non-domestic market. Wildman and Siwek (1993) investigated the economics of trade in recorded media products in a multilingual world.

\section{The proposed study}

This study examines a number of factors suggested in the literature as important determinants of the foreign market selection. Key strategic factors are determined as four groups: host-country characteristics, firm-specific factors, competitive situation and content adaptation. In this study, multiple regression and path analysis is used. To test the model with modeling techniques data from 29 media firms were used. It is based on a questionnaire, which has provided several insights into market selection elements. The following summarizes the hypotheses of the survey,

1. Host-country characteristics influence positively on foreign market selection.

2. Firm-specific factors influence positively on foreign market selection.

3. Competitive situation influence positively on foreign market selection.

4. Content adaptation influence positively on foreign market selection.

The proposed study designed a questionnaire in Likert scale, distributed it among 100 experts and collected 56, which were properly filled. Cronbach alpha has been calculated as 0.81 , which is well above the minimum acceptable level. Fig. 1 demonstrates the structure of the proposed study. 


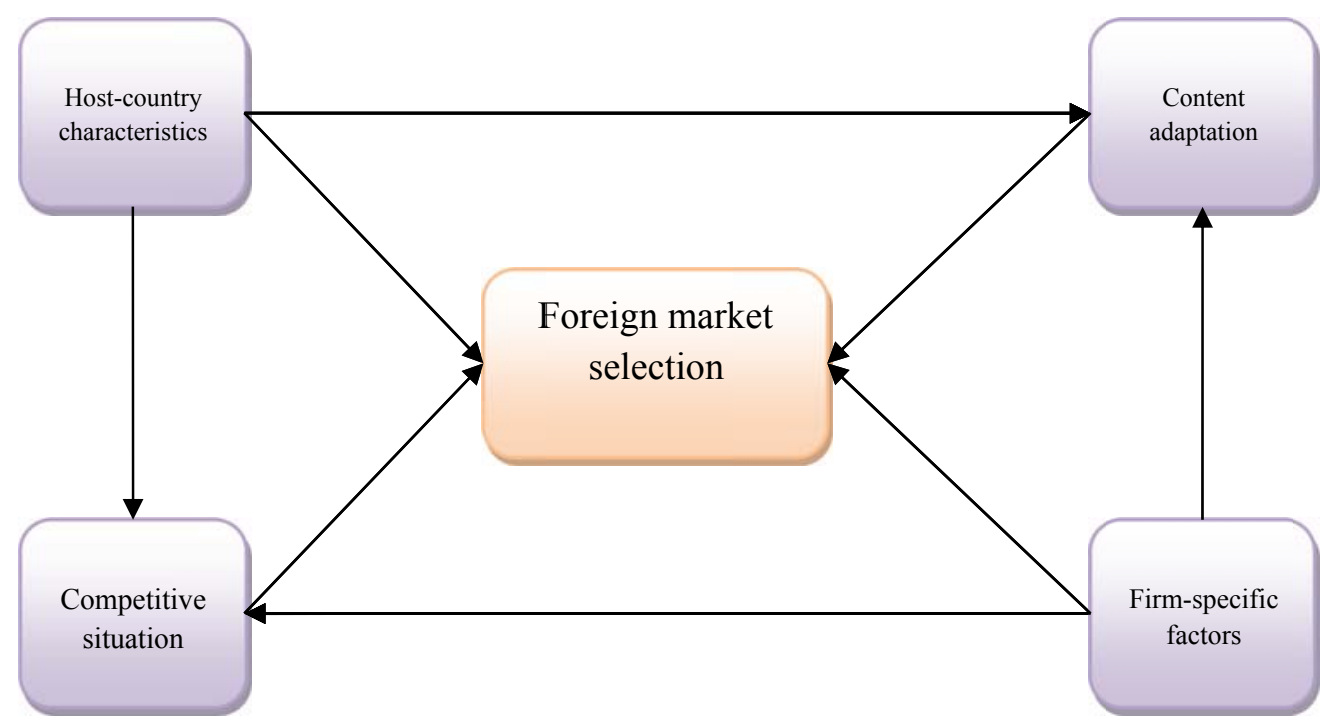

Fig. 1. The structure of the proposed study

\section{The results}

In this section, we present details of our findings on testing the proposed model. Table 1 demonstrates the results of our survey on testing various hypotheses of the survey.

\section{Table 1}

The results of path analysis

\begin{tabular}{llcccc}
\hline Factor & Attribute & Non-standard $(\beta)$ & Standard $(\beta)$ & t-value & Sig. \\
\hline $\begin{array}{l}\text { Content } \\
\text { compatibility }\end{array}$ & Consistency within culture & 0.659 & 0.459 & 5.894 & 0.000 \\
& Compatibility with social elements & 0.622 & 0.443 & 5.519 & 0.02 \\
\hline \multirow{2}{*}{$\begin{array}{l}\text { Country } \\
\text { specification }\end{array}$} & Accessibility & 0.838 & 0.363 & 4.36 & 0.001 \\
& Potential market capabilities & 0.324 & 0.353 & 3.67 & 0.000 \\
& Media infrastructures & 0.838 & 0.254 & 3.159 & 0.02 \\
& Supporting power & 0.818 & 0.242 & 3.05 & 0.000 \\
\hline \multirow{2}{*}{$\begin{array}{l}\text { Competition } \\
\text { status }\end{array}$} & Market structure & 0.581 & 0.41 & 4.46 & 0.001 \\
\hline \multirow{2}{*}{ Firm specific } & Business environment & 0.412 & 0.398 & 4.562 & 0.000 \\
\hline & Management attributes & 0.261 & 0.431 & 5.218 & 0.01 \\
\hline R-Squanizational attributes & 0.415 & 0.421 & 5.105 & 0.000 \\
\hline
\end{tabular}

R-Square $=0.775$ F-value $=162.21$

As we can observe from the results of Table 1, all components of the survey are meaningful when the level of significance is five percent. In addition, R-Square is equal to 0.775 , which means that the model could describe approximately $78 \%$ of the changes on market components. F-value is equal to 162.21, which also confirm the validity of the model. Table 2 summarizes the results of our survey.

\section{Table 2}

The summary of testing four hypotheses

\begin{tabular}{lccc}
\hline Variable & Direct effect & Indirect effect & Total \\
\hline Host-country $\rightarrow$ foreign market selection & 0.523 & 0.336 & 0.859 \\
Firm-specific $\rightarrow$ foreign market selection & 0.591 & --- & 0.591 \\
Competitive situation $\rightarrow$ foreign market selection & 0.270 & --- & 0.270 \\
Content adaptation $\rightarrow$ foreign market selection & 0.351 & 0.228 & 0.579
\end{tabular}




\section{Conclusion}

In this paper, we have presented an empirical investigation to study the effects of four variables on foreign market selection. The proposed study has implemented path analysis to study the effects of these four variables. Based on the results of our survey, we can conclude that host-country has the highest positive impact on foreign market selection followed by firm-specific, content adaptation and competitive circumstance. The results of our survey have indicated that to learn more about the effects of foreign market, it is necessary to learn more about domestic conditions of a market before taking any possible action. The results have indicated that the adaptation of content was the most effective in choosing a foreign market. In addition, cross-cultural adaptation has been an important component in selection of foreign markets. The results also suggested that the causal relationships between the independent variables were positive and significant, while the relationship between the content adaptation and the competitive situation has not been confirmed.

\section{References}

Albarran, A. B., Chan-Olmsted, S. M., \& Wirth, M. O. (Eds.). (2006). Handbook of media management and economics. Psychology Press.

Cadogan, J. W., Diamantopoulos, A., \& Siguaw, J. A. (2002). Export market-oriented activities: their antecedents and performance consequences. Journal of International Business Studies, 33(3), 615626.

Cavusgil, S. T. (1984). Differences among exporting firms based on their degree of internationalization. Journal of Business Research, 12(2), 195-208.

Cavusgil, S. T., \& Zou, S. (1994). Marketing strategy-performance relationship: an investigation of the empirical link in export market ventures. The Journal of Marketing, 58(1), 1-21.

Chan-Olmsted, S. M. (2005). Competitive strategy for media firms: Strategic and brand management in changing media markets. Routledge.

Chan-Olmsted, S. M., Cha, J., \& Oba, G. (2008). An examination of the host country factors affecting the export of US video media goods. Journal of Media Economics, 21(3), 191-216.

Dahringer, L. D. (1991). Marketing services internationally: barriers and management strategies. Journal of Services Marketing, 5(3), 5-17.

Dimmick, J., \& Rothenbuhler, E. (1984). The theory of the niche: Quantifying competition among media industries. Journal of Communication, 34(1), 103-119.

Dow, D., \& Karunaratna, A. (2006). Developing a multidimensional instrument to measure psychic distance stimuli. Journal of International Business Studies,37(5), 578-602.

Dyck, A., \& Zingales, L. (2002). The corporate governance role of the media(No. w9309). National Bureau of Economic Research.

Erramilli, M. K., \& Rao, C. P. (1990). Choice of foreign market entry modes by service firms: role of market knowledge. MIR: Management International Review, 30(2), 135-150.

Hollifield, C. A. (2004). The economics of international media. Media economics: Theory and practice, $85-106$.

Koch, A. J. (2001). Selecting overseas markets and entry modes: two decision processes or one?. Marketing Intelligence \& Planning, 19(1), 65-75.

Kogut, B., \& Singh, H. (1988). The effect of national culture on the choice of entry mode. Journal of international business studies, 19(3), 411-432.

Papadopoulos, N., \& Denis, J. E. (1988). Inventory, taxonomy and assessment of methods for international market selection. International Marketing Review,5(3), 38-51.

Whitelock, J., \& Jobber, D. (2004). An evaluation of external factors in the decision of UK industrial firms to enter a new non-domestic market: an exploratory study. European Journal of Marketing, 38(11/12), 1437-1455.

Wildman, S. S., \& Siwek, S. E. (1993). The economics of trade in recorded media products in a multilingual world: Implications for national media policies. The international market in film and television programs, 13-40. 